\author{
Fernando Garcia- Hernandez ${ }^{1,2}$ Adrian H. Oskam ${ }^{1}$ and Victor M. Castano ${ }^{1}$
}

\title{
DESIGN AND CONSTRUCTION OF AN INNOVATIVE DEVICE FOR CORROSION TESTING OF MATERIALS IN DIFFERENT EN VIRON MENTS
}

\author{
${ }^{1}$ Centro de Fisica Aplicada y Tecnologia Avanzada, Universidad Nacional Autonoma de Mexico \\ Boulevard J uriquilla 3001, Santiago de Queretaro, Q ueretaro 76230, M exico; castano@fata.unam.mx \\ ${ }^{2}$ Universidad Autonoma de Queretaro, Cerro de las Campanas s/ n, Ciudad Universitaria, \\ Santiago de Queretaro, Queretaro 76010, M exico
}

Received: M arch 03, 2009

(c) Garcia-Hernandez F., Oskam A., Castano V., 2009

\begin{abstract}
Corrosion is the deterioration of a substance (usually a metal) or its properties because of the reaction with its environment. There are many forms of corrosion, some of which are encountered in everyday life. Direct losses due to corrosion are more than $\$ 276$ billion dollars annually $=3.1 \%$ of Gross Domestic Product only in the United States. If we consider the rest of the world this figure would be many times higher. However, corrosion and its control besides of its importance, is often a neglected element in the practice of engineering.

This work presents the design of an innovative low cost device to carry out corrosion testing of materials in different environments. High costs that result from the fabrication of special probes or devices for testing, make it an interesting challenge for the engineer or designer. This original and innovative device has been designed accordingly to both the laboratory equipment which will do the characterization and assessment of the corrosion testing, as well as the "Loop reactor" where testing will be carried out in different environments.
\end{abstract}

Keywords: device design, probes, corrosion, industrial design, testing methods.

\section{Introduction}

A number of techniques such as Electrochemical Impedance Spectroscopy (EIS), Polarization Resistance $(\mathrm{Rp})$, Electrochemical Noise (EN) have been used to monitor and study corrosion rate and type as well as the inhibition mechanism. Recently several studies on corrosion control and corrosion inhibitors have been published [1-5]. On the other hand, spontaneous fluctuation of the current and potential of corroding electrodes, which is commonly referred to as Electrochemical Noise (EN), has been extensively studied in the past two decades in order to understand such corrosion and inhibition mechanisms in various environments [6-9]. This technique (EN) can be used through out a single channel potentiostate with the advantage that all three electrodes can be manufactured of the same material [10].

\section{Original Model}

The operation of this device is described here, only to make clear how expensive, inoperative and complicated it is. A manufactured electrode holder support is installed in the PVC pipe in the loop reactor [11]. A specially manufactured and complicated Teflon ${ }^{\circledR}$ interface connector holds the two working electrodes and the reference electrode. They are in turn mechanically connected by means of wires and screws to the potentiostate. Every time during the test the testing rods have to be pulled out of the Teflon holding support, the testing areas (tips of the rods) cut off by mechanical means and finally after the tests, simply discarded. After cutting the tested material the tips have to be re-machined in a lathe and polished again to the mirror-like state required for testing. Obviously every time before cutting the tips off, the wires have to be unattached removing the screws and once the tip of the rods are ready for the next test, it must be reassembled and repositioned in the support in the Loop Reactor. Excessive labor, machining, material discarding and a little amount of tests for a period of time cause not only a nuisance in operation but also an unreliable way of testing. Extreme care is necessary when mechanical cutting off the tips in order to maintain the testing surface intact takes place.

Potential and current are measured versus time in a water solution acidulated with $\mathrm{HCl}$. There are different methods for the analysis of Electrochemical Noise data 
[12-14]. One common method is the Electrochemical Noise Resistance (Rn) [15-18]. Besides, the Power Spectral Density is used to determine the type of corrosion. This is obtained by transforming the potential series of time with a FFT (Fast Fourier Transform algorithm which will generate a Potential FFT vs. frequency graph). Finally, all the numeric values of the potential vs. frequency graph have absolute logarithms applied, normally using an arbitrary reference value of 1 , in order to obtain a graph of Decibels (dB) vs. log of frequency and from the value of the slope of the curve generated, the type of corrosion will be indicated [19-20].

Considering the degree of complexity encountered in manufacturing the complicated Teflon interface connector as the electrode holder and all the operations needed to prepare and integrate the electrodes for testing, a new approach was sought after considering various factors such as making tests easier, reducing the manufacturing costs of the devices, reduction of the amount of materials being discarded after testing, and finally making it absolutely compatible with the Scanning Electron Microscope (SEM) being used in the characterization and assessment of our testing samples.

\section{Design of $\mathrm{N}$ ew Device}

Considering the mentioned earlier facts, a simpler, more reliable and economical way of corrosion testing proceeding in metallic materials was sought. Perhaps the design and manufacturing of the basic device would be more complicated and costly but only one model of each material would be manufactured to be used in this Loop reactor. Carbon steel, copper, stainless steel, aluminum and brass devices would be manufactured, as in this new and innovative design it would be unnecessary to discard so much materials after the testing routines. The principle of this innovative device is that the working probes or testing samples are small screws with a flat head and their usable surface of $22 \mathrm{~mm}^{2}$ is more than enough for this kind of tests. Even though the screws have to be manufactured from the same bulk material as the holding bars, the costs are considerably lower than disposing great quantities of material, and all the labor involved in cutting parts, re-machining and polishing. The flat surface of these screws are easily re-polished and can be used at least ten times before discarding and make testing more efficient at wise costs (less costs for more testing capacity).

\subsection{Device Description}

The basic innovation is the use of probes with minimal surface $\left(22 \mathrm{~mm}^{2}\right)$ which are easily placed and removed from the main probe holding device. These small testing probes have the shape of a flat head screw; they have threads like a screw which allows them to be fixed on the main probe holding device as well as the holding jig of the electron microscope where corrosion is assessed. There are three identical probes which act as electrodes: one is the test probe, the second one is for reference and the third one is either the ancillary electrode or another working electrode. The main probe holding device has three threaded receptacles made of the same material to be tested, inserted in a Nylamid $\AA$ machined center core. It must be made clear that there must be a probe holding device made of each material to be tested (Carbon steel, copper, stainless steel, aluminum and brass) to eliminate galvanic couple. This way the testing probes are placed in the main probe holding device, which in turn is placed in the electrode holding support of the Loop reactor, the testing is carried out and then in an inverse way, holding device is removed from the Loop reactor, the small probes are removed from the holder and placed in the threaded SEM cylinder probe holders of the microscope where the samples are thoroughly analysed and assessed for corrosion results. For confidentiality reasons, and due to the innovative nature of the device and for illustrating purposes, only a schematic diagram (Fig. 1) is presented to provide an idea of the design itself. The given illustration is non dimensional.

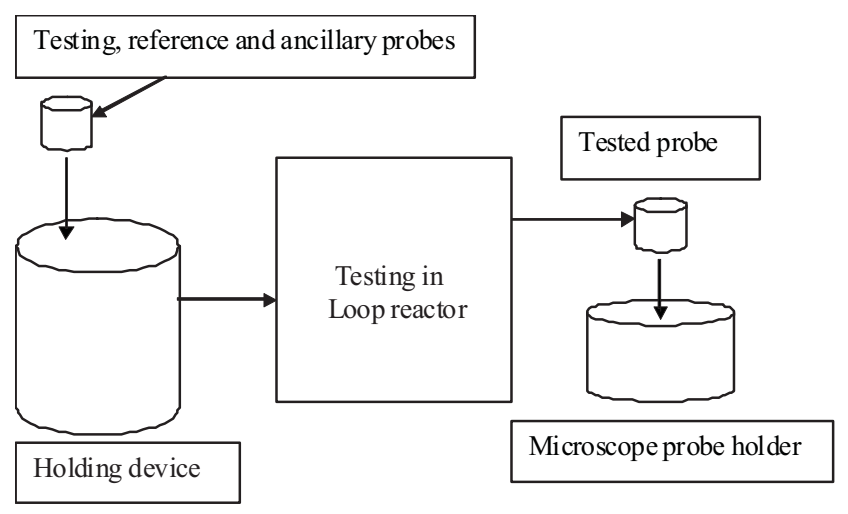

Fig. 1. Schematic diagram of the device

\subsection{Operating Principle}

The main holding device has the capability of all three probes receiving since it has three threaded receptacles. The probes are threaded as well making it possible to install them in the holding device. Once firmly installed the holding device is taken to the loop reactor where it is installed in the commercial fixture that has been used to accept the holding device. The electrodes are connected by means of a quick three lead connector. Once connected the device is ready for testing (see Fig. 2).

After testing has been run, the three lead connector is disconnected, the holding device is removed from the fixture and the testing sample is unscrewed and installed in the threaded jigs which allow to analyse the sample by scanning electron microscope. The reference and other 
working probes can be either left on the holding device or analysed by the SEM to have more reference material.

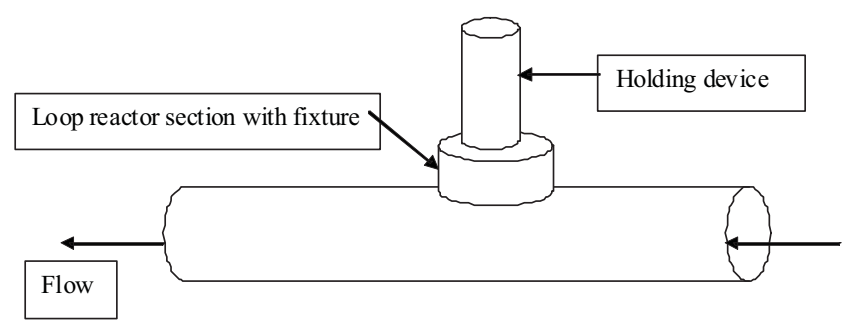

Fig. 2. Probe holding device installed in the Loop reactor fixture

The testing probe requires a highly polished mirrorlike surface which is possible by using 240 to 1500 grit sand papers and a final polish with 0.3 microns alumina powder. The polished samples are examined and photographed before and after any corrosion trial or test, using a "Jeol JSM-6060 LV" Scanning Electron Microscopy system (SEM). The samples are also examined by an Oxford Inca X-Sight Energy Emission Spectroscopy system (EDS) and by a Bruker Vector 33 Infrared Spectroscopy system (IRS).

\section{Conclusions}

The challenge of the design efforts made towards the simplification of testing probes and devices and making them more efficient can be considered not only in reducing costs for the manufacture of these testing devices but also in reducing the time between testing which is finally reflected also in an increase of the amount of testings that can be carried out for any given period of time.

The reduction in discarding of testing materials is considerable, the reduction of manufacturing times, use of machinery, labor, etc., makes this new approach of using very small probes that even if after ten uses they are discarded they make the testing method more efficient and surely innovative. The change of the probe holding device in the Loop reactor takes less than 5 minutes, and one has the capability of changing the material to be tested from one type to another in 5 minutes plus the required testing times.

This innovative design is considered as a novel approach to making testing more productive, easier, faster and also cost effective.

\section{References}

[1] Zin I., Pokhmurskii V., Scantlebury J. and Lyon S.: J. Electrochem. Soc., 2001, 148, B293.

[2] Zin I., Lyon S. and Pokhmurskii V.: Corrosion Sci., 2003, 45, 777.

[3] Pokhmurskii V., Zin I., Bilyi L. et al.: Fizyko-Khimichna Mekhanika Materialiv, 2005, 41, 85.

[4] Duda Y., Govea-Rueda R., Galicia M. et al.: J. Phys. Chem. B, 2005, 109, 22674.

[5] Blawert C., Heitmann V., Dietzel W. et al.: Surf. Coat. Techn., 2007, 201, 8709.

[6] Wang H.: Corrosion/2005, NACE Internacional, , 2005, 05368 .

[7] Uruchurtu-Chavarin J. and Malo J.: Trends in Corrosion Res., 1997, 2, 49.

[8] Bertocci U., Gabrielli C. and Huet F.: J. Electrochem. Soc., 1997a, 144, 31.

[9] Bertocci U., Gabrielli C. and Huet F.: J. Electrochem. Soc., 1997b, 144, 37.

[10] Mojica J.: M.Sc. thesis, National University of Mexico, Mexico, 1998.

[11] D. Rangel-Miranda, Garcia-Hernandez F. and Castano V.: Proc. of the XX Conf. of the Mexican Society of Instrumentation, Mexico, October 24-28, 2005, DRMXX91.

[12] Brusamarello D., Lago A. and Franco C.: Corrosion, 2000, $56,273$.

[13] Cottis R.:Corrosion, 2001, 57, 265.

[14] Aballe A., Bethencourt M., Botana F. and Marcos M.: Electrochem. Acta, 1999, 44, 4805.

[15] Eden D., Hladky K., John D. and Dawson J.: Corrosion/ 86, NACE, Houston, TX, 1986, 274.

[16] Kelly R., Inman M. and Hudson J.: Corrosion Applications, West Conshohocken, PA: ASTM, 1996, 101.

[17] Reichert D.: Corrosion Applications, West Conshohocken, PA: ASTM, 1996, 79.

[18] Mansfeld F. and Xiao H.: J. Electrochem. Soc., 1993, 140, 205. [19] Mojica J., Rodriguez F., Garcia-Ochoa E. and Genesca J.: Corrosion Eng. Sci. Techn., 2004, 39, 131.

[20] Uruchurtu-Chavarin J.: Corrosion, 1991, 47, 472.

\section{МОДЕЛЬ І КОНСТРУКЦІЯ ІННОВАЦІЙНОГО ПРИЛАДУ ДЛЯ ПРОВЕДЕННЯ КОРОЗЙНИХ ТЕСТІВ В РІЗНИХ СЕРЕДОВИЩАХ}

\begin{abstract}
Анотація. Розроблено модель дешевого інноваційного приладу для проведення корозійних тестів в різних середовищах . Показано, щяо ией оригінальний та новітній прилад може використовуватись як лабораторне обладнання для характеристики і очінки корозійних тестувань, а також як «nетельний реактор», який дає можливість проводити тестування зразків у різних середовищах.
\end{abstract}

Ключові слова: модель приладу, проби, корозія, промислова розробка, випробування. 
